\title{
Medical aspects of terrorist bombings - a focus on DCS and DCR
}

\author{
Ventsislav M Mutafchiyski ${ }^{1}$, Georgi I Popivanov ${ }^{2 *}$ and Kirien C Kjossev ${ }^{3}$
}

\begin{abstract}
Although terrorist bombings have tormented the world for a long time, currently they have reached unprecedented levels and become a continuous threat without borders, race or age. Almost all of them are caused by improvised explosive devices. The unpredictability of the terrorist bombings, leading to simultaneous generation of a large number of casualties and severe "multidimensional" blast trauma require a constant vigilance and preparedness of every hospital worldwide. Approximately $1-2.6 \%$ of all trauma patients and $7 \%$ of the combat casualties require a massive blood transfusion. Coagulopathy is presented in $65 \%$ of them with mortality exceeding $50 \%$. Damage control resuscitation is a novel approach, developed in the military practice for treatment of this subgroup of trauma patients. The comparison with the conventional approach revealed mortality reduction with 40-74\%, lower frequency of abdominal compartment syndrome ( $8 \%$ vs. 16\%), sepsis ( $9 \%$ vs. $20 \%$ ), multiorgan failure (16\% vs. $37 \%)$ and a significant reduction of resuscitation volumes, both crystalloids and blood products. DCS and DCR are promising new approaches, contributing for the mortality reduction among the most severely wounded patients. Despite the lack of consensus about the optimal ratio of the blood products and the possible influence of the survival bias, we think that DCR carries survival benefit and recommend it in trauma patients with exsanguinating bleeding.
\end{abstract}

Keywords: Terrorist bombings, Traumatic coagulopathy, Damage control resuscitation

\section{Introduction}

Although terrorist bombings have tormented the world for a long time, currently they have reached unprecedented levels and become a continuous threat without borders, race or age. Between 1973 and 1983, 5075 bombing attacks with 3689 deaths and 7991 injuries were recorded worldwide [1]. In USA, only for 1990, there were 1582 bombings with 222 injuries and 27 deaths, whereas for the period 1990-95 there were 15 700 incidents with 3176 injuries and 355 deaths [2]. The peak is the notorious collapse of the World Trade Center (2001) caused 2819 deaths, the train bombings in Madrid (2004) led to 191 deaths and 2000 injured and the attacks in London (2005) with 56 deaths and over 700 injured. In Israel, for the period 2000-2002 there were 1116 terror-related events [3].

\footnotetext{
* Correspondence: gerasimpopivanov@rocketmail.com

${ }^{2}$ Clinic of Abdominal Surgery, Military Medical Detachment of Emergency Response, Military Medical Academy, 3 "Georgi Sofiiski" Str., Sofia, Bulgaria
} Full list of author information is available at the end of the article

\section{Characteristic of the modern blast trauma}

Approximately $64 \%$ of the combat injuries and most of the civilian ones are caused by improvised explosive devices (IEDs) [4]. In contrast to the military setting, the civilian bombings generate a higher dead/wounded ratio, 5-22 vs. 1:2-1:5 [5]. The blast trauma has unique, "multidimensional" injury pattern due to the simultaneous action of four injury mechanisms [6].

Primary blast injuries (55\%) are result from the blast wave and affect the air-containing organs (lung, tympanic membrane, bowels). Usually, blast lung is manifested 24-48 after the blast and was found in $47 \%$ of the cases with immediate death, accounted for $11 \%$ mortality among the survivors [7]. Blast bowel injuries occur in only $1.2 \%$.

Secondary blast injuries $(60-70 \%)$ are caused by the secondary fragments (SFs) produced by the blast. SFs injuries are multiple and require a special awareness during the initial evaluation for several reasons $[8,9]$. The multiple superficial wound can cause exsanguinating bleeding along with the possibility for multiple body 
cavities penetration, including vessels. The multiple injuries of the viscera require meticulous exploration of the entire abdominal cavity during the laparotomy. Additionally, there is a risk for transmission of infections such as AIDS and hepatitis [10].

Tertiary blast injuries (27-35\%) are result from the body displacement by the blast wind and the structural collapse of the buildings. They lead to different kinds of blunt trauma - acceleration-deceleration injuries (usually of solid organs), fractures, traumatic amputations and head trauma. Severe brain injuries account for $71 \%$ of the immediate and $52 \%$ of the late fatalities [Fryc88].

Quaternary blast injuries constitute about $10 \%$ of all injuries and include burns, commonly associated with inhalation injuries and chemical poisoning [11].

In a comprehensive analysis comparing 906 blast victims and 55033 patients with conventional traumas, Kluger et al., found that blast is associated with severer trauma (ISS > 16 in $28.7 \%$ vs. $10 \%$ ), with multiple body regions involvement $(>3,28.3 \%$ vs. $6.2 \%)$, and higher proportion of those requiring different kind of surgery $(50.8 \%$ vs. 36.6\%) [12]. Blast victims (BVs) suffered more frequently from internal injuries ( $32 \%$ vs. $23 \%$ ), open wounds ( $59 \%$ vs. $17 \%)$, burns ( $17 \%$ vs. $5 \%)$, nerves and blood vessels injuries ( $8 \%$ vs. $1 \%$ and $4 \%$ vs. $1 \%$, respectively), and higher requirements for blood and blood products (5.4\% vs. $1.4 \%)$ [13]. BVs required more frequent intubation (12.2\% vs. $1.9 \%)$, chest decompression (5.9\% vs. $1.3 \%)$, ED thoracotomy (1.2\% vs. $0.2 \%)$ and angiographies $(2.9 \%$ vs. $0.4 \%$ ) at the admission. Blast victims were more frequently in ICU ( $26 \%$ vs. $7 \%)$, with higher mortality rates $(6.1 \%$ vs. $2 \%)$ and rehabilitation needs (12.9\% vs. $8.2 \%)$ [12].

Approximately $1-2.6 \%$ of all trauma patients and $7 \%$ of the combat casualties require a massive blood transfusion (MT) $[14,15]$. Coagulopathy is presented in $65 \%$ of them with mortality exceeding $50 \%$ [14]. The risk factors for MT are systolic blood pressure $<110 \mathrm{mmHg}$, pulse > 105 , hematocrit $<32, \mathrm{pH} 7.25$. In the presence of 3 or 4 of them, the risk is $70 \%$ and $85 \%$, respectively [14]. According to Moore, the combination of ISS $>25, \mathrm{pH}<$ 7.10, mean arterial pressure $<70 \mathrm{mmHg}$ and $\mathrm{T}<34^{\circ}$ leads to coagulopathy in $98 \%$ of the cases [16].

Analysis of 82 cases, died in Iraq in Special Forces Operations, revealed that 12 of them (15\%) were potentially survivable. $8 / 12(66.7 \%)$ or $9.8 \%$ of all $(8 / 82)$ were due to truncal hemorrhage with potential benefit from damage control resuscitation (DCR) [17].

Damage control surgery (DCS) and damage control resuscitation (DCR) were developed in the last 3 decades with aim to diminish mortality within subgroup of the patients with exsanguinating bleeding, thought as unsalvageable with the conventional approach. They are implicitly interrelated and in fact DCS can be considered as a part of DCR.

\section{Damage control surgery (DCS)}

In 1983, Stone and al., first reported a series of 17 patients treated by a rapid control of the bleeding, open abdomen and definitive operation after physiologic stabilization. Twelve of them survived (70.9\%) versus $1 / 12(8.3 \%)$ treated conventionally [18]. The term "damage control" was introduced in 1993 by Rotondo and al. [19]. Subsequent studies reported 33\%-89\% reduction of the mortality rates [20-22]. A cumulative analysis of 1 001 damage control laparotomies revealed overall mortality $50 \%$ and morbidity rate of $40 \%$ [23].

The aim of DCS is to stop the so-called lethal triad - hypothermia $\left(\mathrm{T}<35^{\circ}\right)$, acidosis $(\mathrm{pH}<7.2$, lactate level $>2.5 \mathrm{mmol} / \mathrm{l}$ ) and coagulopathy (INR $>1.6$, aPTT $>$ $60 \mathrm{sec}$.) [16]. The indications for DCS are exsanguinating bleeding with early onset coagulopathy, inaccessible great venous injuries (retrohepatic vena cava, pelvic veins), presence of extra-abdominal life-threatening injuries, inability for definitive repair due to mass casualty influx, lack of qualification or equipment, a need for timeconsuming procedures ( $>90 \mathrm{~min}$.) on the background of persisting hemodynamic instability [24-26]. It consists of four steps.

Ground 0 includes early recognition of the need for DCS, aggressive warming and resuscitation with blood products with subsequent rapid transfer to the operating theater [27]. The second step is a rapid control of hemorrhage and contamination ("resuscitative surgery"). Control of the contamination is best performed through a bowel stapler resection, simple suture/ligation or only clamping of the injured bowel segment. Hemorrhage control includes splenectomy, nephrectomy, temporary shunts or abdominal package. This stage should be limited to 1 hour and as a rule the abdomen is left opened. V.A.C. Abdominal Dressing System is an excellent method for temporary abdominal coverage. It provides good splinting of the abdominal wall, prevention of adhesions and lateral retraction of the fascia, which reflects in higher rate of primary facial closure, diminished risk for ACS and enteroathmospheric fistulas [28-30]. The next steps are damage control resuscitation, followed by definitive repair of the injuries after restoration of the normal physiology.

\section{Damage control resuscitation (DCR)}

The aim of DCR is minimizing of the blood loss, improvement of the tissue oxygenation, normalization of physiology and preparation for the next stage of definitive repair of the injuries [31,32]. The importance of this step is well-illustrated by the thought of the great surgeon lord Moynihan: "The modern operation is safe for the patient. The modern surgeon must make the patient safe for the modern operation."

Traumatic coagulopathy (TC) occurs early after the trauma and is presented at the patient admission $[33,34]$. 
On one hand, TC is due to shock-induced tissue damage, hypoxia and ischemia, which lead to release of proinflammatory cytokines, cateholamines, an activation of complement and coagulation cascade with subsequent consumption coagulopathy and hyperfibrinolysis $[33,34]$. On other hand, hypothermia, acidosis and hemodilution in the cases with severe trauma are significant contributing factors. The combination of ISS $>25, \mathrm{pH}<7.10$, MAP $<70 \mathrm{mmHg}$ and $\mathrm{T}<34^{\circ}$ leads to TC in $98 \%$ of the cases $[16,35]$. Characteristic features of TC are hyperfibrinolysis, activation of tissue-type plasminogen activator (tPA), lack of microtrombi, thrombomodulin-protein $\mathrm{C}$ activation and decreased levels of protein $\mathrm{C}$ and antithrombin III [34,36-38].

The failure of the standard resuscitation is attributed to massive crystalloid administration, which leads to hemodilution and reperfusion injuries, worsening the tissue perfusion, acidosis, coagulopathy and systematic inflammatory response. These events reflect in a higher frequency of ACS and multiple organ failure (MOF) [39-41].

DCR includes three major components: (1) permissive hypotension - keeping a blood pressure at $90 \mathrm{mmHg}$ or palpable pulse in a conscious patient until definitive control of the bleeding [14,41-44], (2) minimal use of crystalloids, and (3) a rapid administration of blood products (PRBC, FFP, platelets) in ratio 1:1:1 in the military practice (translated in 6 units PRBC, 6 units FFP and 1 unit apheresis platelets) [36,45-50]. TEG/ROTEM is recommended as a rapid test for investigation of the coagulation status [51].

The administration of recombinant FVII is controversial. Although it is recommended by JTTS and European consensus, in a randomized control trial, Hauser et al. found reduced blood products use, but no survival benefit $[51,52]$.

Fibrinogen concentrate or cryoprecipitate are associated with improved survival should be administrated when plasma fibrinogen level is less than $1 \mathrm{~g} / \mathrm{l}$ at an initial dose of 3-4 g or $50 \mathrm{mg} / \mathrm{kg}$, respectively or in cryoprecipitate:PRBC ratio 1:1 [51,53].

Tranexamic acid (TEA) is a competitive inhibitor of plasmin and plasminogen and is considered in the patients with trauma coagulopathy due to the recognition of the early activation of the hyperfibrinolysis [33,34]. A retrospective military study (MATTERs) showed significantly lower mortality within the TEA group than noTEA group (17.4\% vs. $23.9 \%)$, which was more pronounced in the group of the patients with MT (14.4\% vs. 28.1\%, OR 7.22) [54]. The randomized placebocontrolled trial Crash-2, including 20211 trauma patients, found significant reduced mortality in patients with massive bleeding (OR 0.85) after administration of TEA. However, this effect was evident when TEA was given within the first 1 hour (RR 0.68 ) and $1-3$ hours (RR 0.79) after the trauma event. Importantly, the treatment given after $3 \mathrm{~h}$ was associated with increased risk for bleeding and death (RR 1.44, p $<0.05$ [55]. On other hand, this beneficial effect may be attributed to the large sample size. Additionally, no significant differences in transfusion requirements between the two groups were recorded. TEA should be given as early as possible after trauma in all patients requiring MT. TEG/ROTEM is recommended for monitoring of the fibrinolysis and to direct the treatment [35].

There is no consensus about the optimal ratio FFP: RPBC. Most authors demonstrated that ratios greater than $1: 2$ were associated with reduced mortality $[35,43,46,47,50]$. In univariate analysis, Duchesne et al., found significantly reduced mortality rate (1:1 vs. 1:4, $26 \%$ vs. $87.5 \%$ ) among the patients received $>10$ units of PRBC, whereas the multivariate analysis revealed relative risk for mortality of 18.9 in ratio 1:4 [47]. In a more recent study, the same author found improved 30-day survival in a greater ratio ( $73.6 \%$ vs. $54.8 \%, 1: 1.2$ vs. $1: 4.2)$ [56].

The reported decrease of the mortality rates varies between $19 \%$ vs. $65 \%$ ( 1 vs. $1: 1.4$ ) [57], $20 \%$ vs. $31 \%$ (1:1.3 vs. $1: 1.6)$ [50], $40 \%$ vs. $60 \%$ (>1:2 vs. <1:2) [58]. Cotton et al., revealed a striking reduction of mortality rate with $74 \%$ [59] and also a lower frequency of ACS ( $8 \%$ vs. $16 \%)$, sepsis ( $9 \%$ vs. $20 \%$ ) and MOFS (16\% vs. $37 \%)$ in comparison to the conventional approach [42]. In other study, the same author reported a significant reduction of resuscitation volumes, both crystalloids and blood products, and improved 24-hour and 30-day survival of the patients received DCR [60].

Despite the optimistic results, several problems should be additionally discussed. First of all, the frequency of ARDS and multiorgan failure (MOF) after MT and their effect on mortality still need to be elucidated [61]. RBC transfusion itself is associated with increased risk for ARDS and MOF [15,62]. Meta-analysis revealed that the high plasma:PRBC ratios in a setting of MT were associated with increased ARDS risk (OR, 2.92). Nevertheless, they were associated with mortality reduction (OR, 0.38) [63]. Park et al., also found a higher frequency of ARDS in MT (8.45 vs. $5.3 \%)$, but without significant difference in the mortality (17.4\% vs.16.3\%) among the combat casualties from Iraq and Afghanistan [64].

Intriguingly, a recent, multicenter, prospective trial in 106 patients, based on TEG monitoring and serum lactate measurement, showed that DCR is "neither hemostatic, nor resuscitative" [65].

It should be mentioned that the reported lower mortality rates in higher ratios may be a result of so-called survival bias (SB). Due to the common practice RPBC to be administered firstly and as most deaths occurred in the first hours after the trauma, it has been suggested 
that the patient who live longer are likely to receive more blood product and to achieve higher FFP:PRBC ratio [66]. However, Ho et al., showed that from 21 studies, showing a survival benefit, 11 were SB-prone and 10 SB-unlikely. Five SB-unlikely studies showed no benefit in high ratios [67]. Two recent studies addressed SB and found that the improved survival is not influenced by SB. A multicenter prospective study found that high FFP:PRBC and platelets:PRBC ratios were associated with improved survival as early as 6 hours and throughout the first 24 hours [68]. Similarly, the Prospective, Observational, Multicenter, Major Trauma Transfusion (PROMMTT) study, including 905 patients from 10 Trauma centers, found decreased 6-hour mortality in high FFP:PRBC (HR, 0.31) [69].

At last, but not least, the definition of MT protocol varies between different Institutions and usually includes over $10 \mathrm{U}$ PRBC/24 hours [35,45]. Kashuk et al., proposed this definition to be changed to $10 \mathrm{U}$ per 6 hours [70]. To avoid the possible selection bias, Savage et al., propose a new definition, which includes $>3 \mathrm{U}$ PRBC for 1 hour within the first 24 hours after the trauma [71]. The authors found that this critical administration threshold (CAT) had a stronger association with mortality vs MP. (RR, 3.58 vs. 1.82 ). CAT identified $75 \%$ of the deaths, while MT identified only $33 \%$.

The need for randomized controlled trials and multicenter collaboration due to the relatively small number of patients requiring DCR in a civilian setting is obvious [14]. We are waiting with interest the results from the recent randomized trial PROPPR, which includes 608 patients and compares the effectiveness of 2:1:1 and 1:1:1 ratios [72].

\section{Conclusion}

The unpredictability of the terrorist bombings, leading to simultaneous generation of a large number of casualties and severe "multidimensional" blast trauma require a constant vigilance and preparedness of every hospital worldwide.

DCS and DCR are promising new approaches, contributing for the mortality reduction among the most severely wounded patients. Despite the lack of consensus about the optimal ratio of the blood products and the possible influence of the survival bias, we think that DCR carries survival benefit and recommend it in trauma patients with exsanguinating bleeding.

\section{Competing interests}

The authors declare no conflict of interests.

\section{Authors' contributions}

VMM wrote DCR section and performed the second revision, GIP wrote the manuscript and performed a part of the literature search, KMK did the literature search and analyzed the data. All authors read and approved the final manuscript.

\section{Author details}

'Endocrine Surgery and Coloproctology, Military Medical Academy, Sofia, Bulgaria. ${ }^{2}$ Clinic of Abdominal Surgery, Military Medical Detachment of Emergency Response, Military Medical Academy, 3 "Georgi Sofiiski" Str., Sofia, Bulgaria. ${ }^{3}$ Clinic of Abdominal Surgery, Military Medical Academy, Sofia, Bulgaria.

Received: 7 May 2014 Accepted: 1 June 2014

Published: 11 June 2014

\section{References}

1. Frykberg ER: Medical management of disasters and mass casualties from terrorist bombings: How can we cope? J Trauma 2002, 53:201-212.

2. Baskin TW, Holcomb JB: Bombs, mines, blast, fragmentation, and thermobaric mechanisms of injury. In Ballistic trauma: a practical guide. 2nd edition. Edited by Mahoney PF, Ryan J, Brooks AJ, Schwab CW. London: Springer; 2005. Chapter 3.

3. Einav S, Feigenberg Z, Weissman C, Zaichik D, Caspi G, Kotler D, Freund H: Evacuation priorities in mass casualty terror-related events. Ann Surg 2004, 239:304-310

4. Willy C, Hauer T, Huschitt N, Palm HG: 'Einsatzchirurgie' - experience of German military surgeons in Afghanistan. Langebecks Arch Surg 2011, 396:507-522.

5. Almogy G, Belzberg H, Mintz Y, Pikarsky A, Zamir G, Rivkind A: Suicide bombing attacks. Update and modifications to the protocol. Ann Surg 2004, 239:295-303.

6. Kluger Y: Bomb explosions in acts of terrorism - detonation, wound ballistics, triage and medical concerns. IMAJ 2003, 5:235-240.

7. Frykberg ER, Tepas JJ: Terrorist bombings. Lessons learned from Belfast to Beirut. Ann Surg 1988, 208(5):569-576.

8. Sheffy N, Mintz Y, Rivkind Al, Shapira SC: Terror-related injuries: a comparison of gunshot wounds versus secondary-fragments - induced injuries from explosives. J Am Coll Surg 2006, 203:297-303.

9. Kluger $Y$, Mayo $A$ : Medical consequences of terrorist bombs containing spherical metal pellets: analysis of a suicide terrorism event. Eur J Emerg Med 2005, 12:19-23.

10. Braverman I, Wexler D, Oren M: A novel mode of infection with hepatitis B: penetrating bone fragments due to the explosion of a suicide bomber. Isr Med Assoc J 2002, 4:525-529.

11. Wolf SE, Kauvar DS, Wade CE, Cancio L, Renz E, Horvath E, White C, Park M, Wanek S, Albrecht M, Blackbourne L, Barillo D, Holcomb J: Comparison between civilian burns and combat burns from operation Iraqi Freedom and operation Enduring Freedom. Ann Surg 2006, 243:786-795.

12. Kluger Y, Peleg K, Daniel-Aharonson L, Mayo A: The special injury pattern in terrorist bombings. J Am Coll Surg 2004, 199:875-879.

13. Aharonson-Daniel L, Klein Y, Peleg K: Suicide bombers form a new injury profile. Ann Surg 2006, 244:1018-1023.

14. Holcomb JB, Jenkins $D$, Rhee P, Johannigman J, Mahoney P, Mehta S, Cox E, Gehrke M, Beilman G, Schreiber M, Flaherty S, Grathwohl K, Spinella P, Perkins J, Beekly A, McMullin N, Park M, Gonzalez E, Wade C, Dubick M, Schwab W, Moore F, Champion H, Hoyt D, Hess J: Damage Control Resuscitation: directly addressing the early coagulopathy of trauma. J Trauma 2007, 62:307-310

15. Shaz BH, Dente CJ, Harris RS, MacLeod J, Hillyer C: Transfusion management of trauma patients. Anesth Analg 2009, 108:1760-1768.

16. Moore EE, Burch JM, Franciose RJ, Offner P, Biffl W: Staged physiologic restoration and damage control surgery. World J Surg 1998, 22:1184-1191.

17. Holcomb JB, McMullin NR, Pearse L, Caruso J, Wade C, Oetjen-Gerdes L, Champion H, Lawnick M, Farr W, Rodriguez S, Butler F: Causes of death in U.S. Special Operations Forces in the Global war on terrorism. Ann Surg 2007, 245:986-991.

18. Stone HH, Strom PR, Mullins RJ: Management of the major coagulopathy with onset during laparotomy. Ann Surg 1983, 197:532-535.

19. Rotondo M, Schwab CW, McGonigal M, Phillips G, Fruchterman T, Kauder D, Latenser B, Angood P: Damage control: an approach for improved survival in exsanguinating penetrating abdominal injury. J Trauma 1993, 35:375-383.

20. Burch JM, Otiz VB, Richardson RJ, Martin R, Mattox K, Jordan G: Abbreviated laparotomy and planned reoperation for critically injured patients. Ann Surg 1992, 215(5):476-483. 
21. Ivatury RR, Nallathambi M, Gunduz Y, Constable R, Rohman M, Stahl WM: Liver packing for uncontrolled hemorrhage: a reappraisal. J Trauma 1986, 26:744-753

22. Sharp K, Locicero RJ: Abdominal packing for surgically uncontrollable hemorrhage. Ann Surg 1992, 215:467-474

23. Shapiro MB, Jenkins DH, Schwab W, Rotondo M: Damage control: collective review. J Trauma 2000, 49:969-978.

24. Midwinter MJ: Damage control surgery in the Era of damage control resuscitation. JR Army Med Corp 2009, 155(4):323-326.

25. Hoey BA, Schwab CW: Damage control surgery. Scand J Surg 2002, 91:92-103.

26. Rotondo M, Zonies D: The damage control sequence and underlying logic. Surg Clin N Am 1997, 77:761-777.

27. Johnson JW, Gracias VH, Schwab CW, et al: Evolution in damage control for exsanguinating penetrating abdominal injury. J Trauma 2001, 51(2):261-269

28. Stone PA, Hass SM, Flaherty SK, DeLuca J, Lucente F, Kusminsky R: Vacuum-assisted fascial closure for patients with abdominal trauma. J Trauma 2004, 57:1082-1086.

29. Miller PR, Meredith JW, Johnson JC, Chang M: Prospective evaluation of vacuum-assisted fascial closure after open abdomen: planned ventral hernia is substantially reduced. Ann Surg 2004, 239:608-614.

30. Miller RS, Morris JA Jr, Diaz JJ, Herring MB, May AK: Complications after 344 damage-control open celiotomies. J Trauma 2005, 59:1365-137.

31. Holcomb JB, Nunez TC: Damage Control Resuscitation. In Front Line Surgery. Edited by Martin M, Beekley A. New York: Springer; 2011:47-58.

32. Hodgetts TJ, Mahoney PF, Kirkman E: Damage control resuscitation. JR Army Med Corps 2008, 153(4):299-300.

33. Gando S, Sawamura A, Hayakawa M: Trauma, shock, and disseminated intravascular coagulation. Ann Surg 2011, 254:10-19.

34. Gebhard F, Huber-Lang M: Polytrauma - pathophysiology and management principles. Langebecks Arch Surg 2008, 393:825-831.

35. Johansson PI, Ostriwski SR, Secher NH: Management of major blood loss: an update. Acta Anaesthesiol Scand 2010, 54:1039-1049.

36. Ho AM, Dion PW, Cheng CA, Karmakar MK, Cheng G, Penq Z, Way NG, Karmakar MK, Cheng G, Penq Z, Way NG: A mathematical model for fresh frozen plasma transfusion strategies during major trauma resuscitation with ongoing hemorrhage. Can J Surg 2005, 48:470-478.

37. Brohi K, Singh J, Heron M, Coats T: Acute traumatic coagulopathy. J Trauma 2003, 54:1127-1130.

38. Faringer PD, Mullins RJ, Johnson RL, Trunkey DD: Blood component supplementation during massive transfusion of AS-1 red cells in trauma patients. J Trauma 1993, 34:481-485.

39. Ertmer C, Kampmeier T, Rehberg $\mathrm{S}$, et al: Fluid resuscitation in multiple trauma patients. Curr Opin Anesthesiol 2011, 24:202-208

40. Cotton BA, Guy JS, Morris JA, et al: The cellular, metabolic, and systemic consequences of aggressive fluid resuscitation strategies. Shock 2006, 26:115-121.

41. Coimbra R, Hoyt DB, Junger WG, et al: Hypertonic saline resuscitation decreases susceptibility to sepsis after hemorrhagic shock. J Trauma 1997, 42:602-606.

42. Cotton BA, Au BK, Nunez TC, et al: Predefined massive transfusion protocols are associated with a reduction in organ failure and postinjury complications. J Trauma 2009, 66:41-48.

43. Rhee $P$, Koustova $E$, Alam HB: Searching for the optimal resuscitation method: recommendations for the initial fluid resuscitation of combat casualties. J Trauma 2003, 54(Suppl 5):52-62.

44. Ayuste EC, Chen H, Koustova E, et al: Hepatic and pulmonary apoptosis after hemorrhagic shock in swine can be reduced through modifications of conventional Ringer's solution. J Trauma 2006, 60:52-63.

45. Joint Theater Trauma System Clinical Practice Guideline: Damage control resuscitation at level $\mathrm{Ilb} / \mathrm{III}$ treatment facilities.

46. Duchesne JC, Holcomb JB: Damage control resuscitation: addressing trauma-induced coagulopathy. Br J Hospit Med 2009, 70(1):22-25.

47. Duchesne JC, Hunt JP, Wahl G, et al: Review of current blood transfusions strategies in a mature level I trauma center: were we wrong for the last 60 years? J Trauma 2008, 65:272-276

48. Malone $\mathrm{DL}$, Hess JR, Fingerhut A: Massive transfusion practices around the globe and a suggestion for a common massive transfusion protocol. J Trauma 2006, 60(Suppl 6):91-96.
49. Ketchum L, Hess JR, Hiippala S: Indications for early fresh frozen plasma, cryoprecipitate, and platelet transfusion in trauma. J Trauma 2006 60(Suppl 6):51-58.

50. Johansson $\mathrm{Pl}$, Stensballe J: Effect of haemostatic control resuscitation on mortality in massively bleeding patients: a before and after study. Vox Sang 2009, 96:111-118.

51. Spahn DR, Cerny V, Coats TJ, Duranteau J, Fernadez-Mondejar E, Gordini G, Stahel P, Hunt B, Komadina R, Neugebauer E, Ozier Y, Riddez L, Schultz A, Vincent J-L, Rossaint R: Management of bleeding following major trauma: a European guideline. Crit Care 2007, 11:R17. doi:10.1186/cc5686.

52. Hauser CJ, Boffard K, Durron R, Dutton R, Bernard G, Croce M, Holcomb J, Leppaniemi A, Parr M, Vincent J, Tortella B, Dimsits J, Bouillon B, CONTROL Study Group: Results of the CONTROL trial: efficacy and safety of recombinant activated factor VII in the management of refractory traumatic hemorrhage. J Trauma 2010, 69(3):489-500.

53. Miller TE: New evidence in trauma resuscitation - is 1:1:1 the answer? Perioperative medicine 2013, 2:13.

54. Morison JJ, Dubose JJ, Rasmussen TE, Midwinter MJ: Military application of tranexamic acid in trauma emergency resuscitation (MATTERs) study. Arch Surg 2011 2011. doi:10.1001/archsurg.2011.287.

55. The CRASH-2 collaborators: The importance of early treatment with transexamic acid in bleeding trauma patients: an exploratory analysis of the CRASH-2 randomized controlled trial. Lancet 2011. doi:10.1016/S0140-6736(11)60278-X.

56. Duchesne JC, Kimonis $K$, Marr AB, et al: Damage control resuscitation in combination of damage control surgery: a survival advantage. J Trauma 2010, 69(1):46-52.

57. Borgman MA, Spinella PC, Perkins JG, Grathwohl KW, Repine T, Beekly AC, Sebesta J, Jenkins D, Wade CE, Holcomb JB: The ratio of blood products transfused affects mortality in patients receiving massive transfusions at a combat support hospital. J Trauma 2007, 63:805-813.

58. Holcomb JB, Wade CE, Michalek JE, Chisholm GB, Zarzabai LA, Schreiber MA Gonzales EA, Pomper GJ, Perkins JG, Spinella PC, Williams KL, Park MS: Increased plasma and platelet to red blood cell ratios improves outcome in 466 massively transfused civilian trauma patients. Ann Surg 2008, 248:447-458.

59. Cotton BA, Gunter OL, Isbell J, Au BK, Robertson AM, Morris JA, Jacques P, Young PP: Damage control hematology: the impact of a trauma exsanguination protocol on survival and blood product utilization. J Trauma 2008, 64:1177-1182.

60. Cotton BA, Reddy N, Hatch QM, Lefebre E, Wade CE, Kozar RA, Gill BS, Albarado R, McNutt MK, Holcomb JB: Damage control resuscitation is associated with a reduction in resuscitation volumes and improvement in survival in 390 damage control laparotomy patients. Ann Surg 2011, 254:598-605.

61. Maegele $M$, Lefering R, Paffrath $T$, Tjardes $T$, Simanski C, Bouilon B: Red blood cell to plasma ratios transfused during massive transfusion are associated with mortality in severe multiple injury: a retrospective analysis from the Trauma Registry of the Deutsche Gesellschaft für Unfallchirurgie. Vox Sang 2008, 95:112-119.

62. Tinmouth A, Fergusson D, Yee IC, Hebert P: Clinical consequences of red cell storage in the critically ill. Transfusion 2006, 46:2014-2027.

63. Murad MH, Stubbs JR, Gandhi MJ, Wang AT, Paul A, Erwin PJ, Montori VM, Roback JD: The effect of plasma transfusion on morbidity and mortality: a systematic review and meta-analysis. Transfusion 2010, 50:1370-1383.

64. Park PK, Cannon JW, Ye WY, Blackbourne L, Holcomb J, Beninati W, Napolitano L: Transfusion strategies and development of acute respiratory distress syndrome in combat casualty care. J Trauma Acute Care Surg 2013, 75:S238-S246.

65. Khan S, Brohi K, Chana M, Raza I, Stanworth S, Gaarder C, Davenport R: Hemostatic resuscitation is neither hemostatic nor resuscitative in trauma hemorrhage. J Trauma Acute Care Surg 2014, 76:561-568.

66. Snyder CW, Weinberg JA, McGwin G, Melton SM, George RL, Reiff DA, Cross JM, Hubbard-Brown J, Rue LW, Kerby JD: The relationship of blood product ratio to mortality: survival benefit or survival bias. J Trauma 2009, 66:358-362.

67. Ho AM, Dion PW, Yeung JH, Holcomb JB, Critchley LA, Nq CS, Karmakar MK, Cheung CW, Rainer TH: Prevalence of survivor bias in observational studies on fresh frozen plasma:erythrocyte ratios in trauma requiring massive transfusion. Anesthesiology 2012, 116:716-728. 
68. Brown JB, Cohen MJ, Minei JP, Maier RV, West MA, Billiar TR, Peitzman AB, Moore EE, Cushieri J, Sperry J: Characterization of mortality during the initial 24 hours for patients requiring massive transfusion. J Tauma Acute Care Surg 2012, 73:358-364.

69. Holcomb JB, Del Luco DJ, Fox EE, et al: The Prospective, Observational, Multicenter, Major Trauma Transfusion (PROMMTT) Study: comparative effectiveness of a time-varying treatment with competeting risks. JAMA Surg 2013, 148(2):127-136.

70. Savage SA, Zarzaur BL, Croce MA, Fabian TC: Redefining massive transfusion when every second counts. J Trauma Crit Care Surg 2013, 74(2):396-400. Kashuk JL, Moore EE, Johnson JL, et al.: Postinjury life threatening coagulopathy: is 1:1 fresh frozen plasma:packed red blood cells the answer? J Trauma 2008, 65:261-70.

71. Kashuk JL, Moore EE, Johnson JL, Haenel J, Wilson M, Moore JB, Cothren CC, Biffl WL, Banerjee A, Sauaia A: Postinjury life threatening coagulopathy: is 1:1 fresh frozen plasma:packed red blood cells the answer? J Trauma 2008, 65:261-270

72. Holcomb JB: Pragmatic, Randomized Optimal Platelets and Plasma Ratios (PROPPR). http://clinicaltrials.gov/show/NCT01545232.

doi:10.1186/2054-9369-1-13

Cite this article as: Mutafchiyski et al: Medical aspects of terrorist bombings - a focus on DCS and DCR. Military Medical Research 2014 1:13.

\section{Submit your next manuscript to BioMed Central and take full advantage of:}

- Convenient online submission

- Thorough peer review

- No space constraints or color figure charges

- Immediate publication on acceptance

- Inclusion in PubMed, CAS, Scopus and Google Scholar

- Research which is freely available for redistribution 